\title{
PENTINGNYA MENGHARGAI ORANG LAIN
}

\author{
Hondi Panjaitan \\ Character Building Development Center, BINUS University \\ Jln. Kemanggisan Ilir III No. 45, Kemanggisan - Palmerah, Jakarta 11480 \\ hondipanjaitan@yahoo.com
}

\begin{abstract}
There are many problems in human tragedy occur today, where people kill, harass and commit acts of violence against each other. It can be seen either on electronic or print media. Many things could cause it. However, if the main cause is contemplated, it is because humans do not appreciate others. Man has left his human nature, so he is not able anymore to humanize humans, treate others important and valuable. Humans seem to have started to lose humanity. Humans have failed to maintain their nature as social beings and God's creatures are precious. Man forgets and fails to perform his social responsibility to protect, love and do good and noble. Humans have failed to position and treat others as beings that should be protected and cherished. Animals kill animals, so do humans. Proved there are plenty of people to kill, harass and commit acts of violence against each other, either directly or indirectly. Humans have moral decline, ethics and religion by abandoning the essential dignity. The most surprising is apparently the inability to respect others, not only the uneducated but also the educated. Apparently education is not always directly proportional to good morals. This is proved with the brawl between students, universities and students and faculty. Therefore, every person and especially she/he in the world of education is supposed to teach and emphasize the importance of appreciate others in the learning process and in everyday life in order to create harmony and peace on earth.
\end{abstract}

Keywords: appreciate others, social awareness, social responsibility

\begin{abstract}
ABSTRAK
Ada banyak masalah tragedi kemanusiaan yang terjadi pada saat ini: manusia membunuh, melecehkan, dan melakukan tindakan kekerasan terhadap sesama. Hal ini dapat dilihat dalam media elektronik dan media cetak. Hal itu dapat disebabkan oleh banyak hal. Namun jika direnungkan penyebab utamanya adalah karena manusia tidak mampu menghargai orang lain. Manusia telah meninggalkan sifat kemanusiaannya, sehingga tidak mampu lagi memanusiakan manusia, memperlakukan orang lain sama pentingnya dan berharganya. Jika binatang belum kehilangan kebinatangannya, sepertinya manusia sudah mulai kehilangan kemanusiaannya. Manusia telah gagal menjaga kodratnya sebagai makhluk sosial dan makhluk ciptaan Tuhan yang mulia. Manusia lupa dan gagal melakukan tanggung jawab sosial untuk melindungi,menyayangi, dan melakukan hal yang baik dan mulia. Manusia telah gagal memosisikan dan memperlakukan orang lain sebagai makhluk yang seharusnya dilindungi dan disayangi. Jika binatang membunuh sesamanya, sekarang manusia pun sepertinya tidak mau ketinggalan. Terbukti ada banyak manusia membunuh, melecehkan, dan melakukan tindakan kekerasan terhadap sesamanya, baik secara langsung maupun tidak langsung. Manusia telah mengalami kemerosotan moral, etika, dan agama dengan meninggalkan harkat dan martabatnya yang hakiki. Yang paling mengherankan adalah ternyata ketidakmampuan menghargai orang lain bukan hanya dilakukan kalangan orang tidak terdidik melainkan juga kalangan terdidik. Rupanya tingginya pendidikan seseorang tidak selalu berbanding lurus dengan moral yang baik. Hal ini terbukti terjadinya tawuran antarpelajar, antarperguruan tinggi dan antarmahasiswa dan dosen. Oleh sebab itu, setiap orang dan khususnya dunia pendidikan sudah seharusnya mengajarkan dan menekankan pentingnya menghargai orang lain di dalam proses pembelajaran dan dalam kehidupan sehari-hari demi terciptanya keharmonisan dan kedamaian di bumi ini.
\end{abstract}

Kata kunci: menghargai orang lain, kesadaran sosial, tanggung jawab sosial 


\section{PENDAHULUAN}

Pada saat ini ada kecenderungan manusia tidak lagi dapat menghargai orang lain. Hal ini tidak hanya terjadi di Indonesia, tetapi juga di luar negeri. Ada banyak kejadian yang menyedihkan, memilukan, dan mengerikan yang terjadi akibat manusia tidak dapat menghargai orang lain. Ketidakmampuan menghargai orang lain dapat terlihat dari bentuk dan cara yang paling sederhana seperti pelecehan sekual, sodomi, dan lain-lain sampai ke hal yang paling kasar yaitu melakukan penyiksaan, pembunuhan bahkan pembunuhan massal/sadis. Stott (1994:194-195) mengatakan: "Masih banyak bentuk penyiksaan/penindasan lain. Komisi hak asasi PBB menerima kira-kira 20 ribu pengaduan setiap tahun. Perlakuan tidak adil terhadap golongan minoritas masih saja terjadi di mana-mana." Sebagai contoh, melalui media televisi disiarkan: seorang pemuda membunuh majikan dan anaknya gara-gara dipecat dari pekerjaannya; Riyan membunuh orang-orang terdekatnya secara sadis; pembunuhan massal yang mengerikan dimana sebanyak 26 orang di Sekolah Dasar Sandy Hook, Newtown, Connecticut Amerika Serikat dibunuh dengan senjata api membabi buta. Hal inilah yang mendorong tulisan ini dibuat, untuk mengingatkan dan menggugah kembali hati semua orang akan pentingnya menghargai orang lain. Dengan tujuan agar semua pihak perlu menjaga dan meningkatkan penghargaan kepada orang lain secara nyata dan tulus untuk terus menerus dari generasi ke generasi, dari lingkungan terkecil (keluarga) sampai lingkungan yang lebih luas di mana saja. Inilah saatnya introspeksi diri untuk kembali merenungkan dan mempertanyakan sudah sejauh mana dan sebesar apa penghargaaan terhadap orang lain, seberapa besar usaha yang dilakukan untuk itu. Sesungguhnya penghargaan terhadap orang lain, untuk mendorong dan memperkuat penghargaan terhadap orang lain, seseorang perlu memahami arti menghargai dan pentingnya menghargai orang lain. Penghargaan terhadap orang lain akan menciptakan kedamain dan kebaikan serta meningkatkan kualitas kemanusian diri sendiri.

\section{METODE}

Artikel menggunakan metode kualitatif dengan model studi kepustakaan. Artikel diawali dengan mencari informasi tentang arti menghargai orang lain, selanjutnya alasan penting menghargai orang lain, tujuan menghargai orang lain, hal yang mendasari untuk menghargai orang lain, siapa saja yang harus dihargai. Kemudian, hal yang menyebabkan orang tidak atau kurang dapat menghargai orang lain, bagaimana caranya agar bisa makin menghargai orang lain. Lalu yang terakhir adalah simpulan.

\section{HASIL DAN PEMBAHASAN}

Setiap orang hendaknya sadar bahwa seorang harus bisa dan mau menerima orang lain apa adanya, dalam arti tidak ada diskriminasi. Setiap orang harus mampu menerima seseorang dengan tidak membedakan suku, agama, bahasa, jenis kelamin, dan bangsanya. Setiap orang patut dan layak untuk dihargai dan dihormati. Penerimaan ini harus dilakukan dengan tulus dan penuh kesadaran. Jika seseorang mampu menerima orang lain apa adanya, orang itu pun akan diterima apa adanya. Layaknya hukum tabur tuai, apa yang ditabur seseorang, itu juga yang dituai orang tersebut.

Hal yang tidak kalah pentingnya dalam menghargai orang lain adalah harus mampu memperlakukan orang lain secara baik dan benar, dalam arti sesuai norma dan aturan yang berlaku. Kata "baik" diartikan tidak melecehkan (merendahkan), tidak melakukan tindakan kasar, tidak membunuh, dan segala hal yang bernuansa negatif. Sedangkan kata "benar" artinya sesuai dengan 
aturan yang berlaku, kedudukannya (statusnya) dan tanggung jawabnya. Contohnya, jika dia seorang dosen, perlakukanlah dia dengan baik sebagai manusia yang bermartabat dan hargailah/hormatilah dia sebagai dosen (jabatanya sebagai dosen). Segala sesuatu yang kamu kehendaki supaya orang perbuat kepadamu perbuatlah demikian juga. Harus disadari bahwa sesungguhnya tuntutan untuk menghargai orang lain bukan penekanannya karena seseorang baik, namun juga harus bisa menghargai seseorang sekalipun tidak baik, karena ia adalah manusia yang layak dihargai dan dihormati. Kualitas moral yang paling tinggi adalah jika seorang mampu menghargai orang sekalipun jahat. Karena dengan demikian, dia akan melihat yang baik sehingga terbukalah hatinya untuk bertobat, untuk melakukan yang baik.

Hal yang penting berikutnya dalam menghargai orang lain adalah setiap orang hendaknya memberi ruang atau jalan bagi orang lain untuk maju dan berkembang, yaitu dengan memfasilitasi dan memotivasi. Fasilitas dan motivasi dapat dilakukan baik secara langsung maupun tidak langsung agar orang lain mendapatkan ruang yang cukup untuk mengembangkan bakat, talenta, dan karunia yang dimilikinya secara maksimal. Tidak boleh mengejek dan menghambat orang lain untuk maju dan berkembang.

Hal yang sangat penting untuk dipahami dalam menghargai orang lain adalah bahwa tidak boleh merusak atau mencuri harta milik orang lain, baik harta material maupun nonmaterial seperti mencuri tulisan/hasil karya orang lain (plagiat). Zaman sekarang banyak orang melanggar hal ini. Sebagai contoh, pembajakan di bidang seni (pembajakan karya seni) seperti pembajakan lagu dan pembajakan teknologi yang merugikan penciptanya dan lain-lain.

Hal lain dalam pemahaman menghargai orang lain adalah harus mampu memosisikan atau mendudukkan orang lain sama pentingnya dengan diri sendiri. Artinya, jika seorang merasa diri penting/berharga, dia pun harus sadar juga atau memahami juga bahwa orang lain juga penting dalam arti sama pentingnya atau berharganya dengan diri sendiri. Jika hal ini dapat disadari dan dijalankan dalam kehidupan sehari-hari, seorang akan berkata-kata dan bertindak atau berbuat yang baik terhadap orang lain. Perlakuan seperti ini sesungguhnya adalah meningkatkan harkat dan martabat manusia itu sendiri sebagai makhluk yang mulia, berbudi luhur dan agamais, yang sekaligus menjunjung tinggi hak asasi manusia (HAM).

\section{Pentingnya Menghargai Orang Lain}

Demi terwujudnya dan memantapkan penghargaan terhadap orang lain, seseorang harus memahami juga alasan pentingnya menghargai orang lain. Makin seseorang memahami alasan harus menghargai orang lain, makin baik dan besar pula penghargaan terhadap orang lain. Berikut ini adalah alasan pentingnya menghargai orang lain.

Hal pertama yang harus dipahami sebagai alasan menghargai orang lain adalah semua manusia yang lahir di bumi ini layak dan pantas untuk dihargai. Manusia sama-sama ciptaan Tuhan. Jika ciptaan Tuhan lainnya dihargai, apalagi manusia yang lebih berharga dari segala ciptaan lainya yang ada. Harga manusia tidak dapat diukur. Jika ada yang mengukurnya dengan uang, itu adalah tindakan yang salah dan tidak bermoral.

Alasan kedua harus menghargai orang lain karena semua sama kedudukannya dan sama posisinya di hadapan Tuhan dan hukum. Setiap orang tidak boleh menyombongkan diri dengan menganggap dirinya lebih berharga dan lebih penting dari orang lain. Setiap orang dikasihi dan diterima Tuhan, yang sungguh-sungguh datang mencari dan bertakwa kepada-Nya. Tuhan pencipta manusia tidak membeda-bedakan orang. Surga yang disediakan tidak hanya diperuntukkan untuk suku/etnis, kaum/golongan, bahasa, dan bangsa tertentu, bukan pula disediakan hanya untuk berkulit putih, tetapi juga untuk segala warna kulit termasuk kulit hitam. Demikian juga dengan berkat-Nya, kasih-Nya, atau cinta-Nya disediakan dan diberikan kepada semua orang (disediakan bagi setiap 
suku/etnis, kaum/golongan, bahasa, dan bangsa). Jika Allah yang mahabesar sungguh menghargai dan mencintai manusia apa adanya, apa hebatnya sesorang tidak bisa menghargai orang lain yang adalah sama-sama ciptaan Tuhan juga. Di samping itu, setiap orang seharusnya sadar bahwa manusia sama kedudukannya di dalam hukum, yang artinya sama hak dan kewajibanya. Hal ini sudah diatur dalam Undang-Undang Dasar (UUD 1945) Republik Indonesia. Jadi setiap orang harus menyadari hal ini dengan sungguh-sungguh dan tulus, sehingga tidak ada lagi perbuatan yang tidak menghargai orang lain seperti membunuh, melecehkan, dan melakukan tindakan kekerasan yang melawan hukum. Sesungguhnya siapapun yang melakukan hal ini telah melanggar hukum Tuhan dan hukum dunia (negara) termasuk etika dan moral.

Alasan berikutnya adalah bahwa manusia adalah makhluk yang mulia dan sangat berharga. Setiap manusia harus menyadari bahwa kita adalah makluk yang muliadan sangat berharga. Allah sendiri sudah menyatakan hal ini kepada kita dalam Firman-Nya dalam Yesaya 43 ayat 4: "Sungguh Mulia dan berharga,” (LAI, 2009). Jika Sang Pencipta saja sudah menyatakan hal ini, seharusnya sebagai ciptaan harus menyadari dan menjalankan sepenuh hati untuk selalu menghargai orang lain dengan setulus-tulusnya dan selurus-lurusnya serta sekuat-kuatnya.

Alasan berikutnya adalah manusia makhluk sosial, yang artinya setiap orang tidak bisa hidup sendiri. Manusia saling membutuhkan, saling mencukupkan, dan saling melengkapi. Tanpa kehadiran orang lain hidup tidak lengkap atau tidak sempurna dan tidak bahagia. Sebagai bukti, Allah sendiri berfirman dalam Kejadian 2 ayat 18: “..tidak baik manusia itu hidup sendiri (Adam), Aku akan memberikan seorang penolong baginya (Hawa),” (LAI, 2009). Tanpa kehadiran orang lain (Hawa), maka manusia akan punah. Setiap orang harus sadar bahwa dirinya akan menjadi makin bermakna atau berharga karena penghargaan dari orang lain. Guru berharga karena ada muridnya; dosen berharga karena ada mahasiswanya; penyanyi berharga karena ada penontonnya/pendengarnya; pemimpin berharga karena ada yang dipimpinnya. Seorang menjadi besar juga karena dibesarkan orang lain (orangtua). Suatu produk berharga karena ada pembelinya/pemakainya. Orang kota membutuhkan orang desa dan sebaliknya. Ustaz/pendeta berharga karena ada umatnya. Siapapun dia, apapun status atau jabatannya, pasti membutuhkan orang lain. Sesungguhnya hidup ini menjadi berhaga atau berarti karena kehadiran orang lain. Jadi setiap orang harus berkata bahwa manusia saling membutuhkan, maka penting untuk saling menghargai.

\section{Tujuan Menghargai Orang Lain}

Untuk makin menghargai orang lain, seorang juga harus memahami tujuan menghargai orang lain, yaitu sebagai berikut.

Tujuan menghargai orang lain yang pertama adalah untuk kemuliaan Tuhan. Jika seorang dapat menghargai orang lain dengan tulus, sesungguhnya orang tersebut telah memuliakan/menyenangkan Tuhan karena dia telah mampu mentaati atau melaksanakan perintah-Nya dan menjauhi larangan-Nya. Tuhan, Sang pencipta, telah mengajar manusia untuk hidup saling mengasihi. Siapapun dia yang tidak dapat menghargai orang lain sesungguhnya dia telah melawan perintah Tuhan, tidak menghormati Tuhan sang pencipta manusia dan pemberi hidup. Firman Tuhan dalam 1 Yohanes 5 ayat 18 berkata: "Barang siapa yang berkata mengasihi Tuhan tapi tidak mengasihi orang lain sesungguhnya dia adalah pendusta karena barangsiapa tidak mengasihi saudaranya yang dilihatnya, tidak mungkin mengasi Allah, yang tidak dilihatnya,” (LAI, 2009).

Tujuan berikutnya adalah menciptakan kedamaian. Kedamaian adalah harapan setiap orang. Bahkan negara dan bangsa-bangsa pun merindukan kedamaian. Salah satu syarat utama untuk terciptanya kedamaian adalah ketika seseorang telah mampu secara nyata dan tulus menghargai orang lain. Tragedi kemanusian terjadi karena seorang tidak sungguh-sungguh sadar dan berusaha untuk mampu menghargai orang lain; dan tragedi itu akan makin meluas dan merajalela jika seseorang membiarkan penghargaan terhadap orang lain terus diabaikan atau dibiarkan. Semua orang tanpa 
kecuali pemerintah dan aparat keamaanan harus tegas menindak orang-rang yang tidak menghargai orang lain (melanggar kebebasan/kemerdekaan orang lain) dan sungguh-sunguh berusaha secara sadar dan nyata untuk tetap berjuang dan meningkatkan penghargaan terhadap orang lain dengan membuang kemunafikan, egoisme, dan kepentingan golongan. Kedamaian adalah syarat mutlak terjadinya pembangunan.

Tujuan ketiga dari pelaksanaan penghargaan terhadap orang lain adalah untuk menciptakan kebahagiaan dan kemajuan bersama, bahwa di mana ada kedamaian di situ ada kebahagiaan dan di situ juga akan terjadi kemajuan. Seseorang tidak dapat mengalami kebahagiaan dan kemajuan tidak mampu menghargai orang lain. Sebagai contoh, sebuah keluarga berbahagia jika sesama anggota keluarga saling menghargai. Demikian juga dengan masyarakat tidak akan mengalami kemajuan jika di masyarakat tidak ada penghargaan terhadap orang lain. Justru yang terjadi sebaliknya, yaitu keributan, permusuhan, dan pembunuhan. Karena itu, mari bersungguh-sungguh mau dan terus menghargai orang lain demi kebahagiaan dan kemajuan bersama.

\section{Hal yang Mendasari dalam Menghargai Orang Lain}

Hal-hal yang mendasari atau yang menjadi dasar seseorang menghargai orang lain adalah sebagai berikut.

Setiap orang adalah ciptaan Tuhan, maka sudah barang tentu setiap orang juga memiliki kasih/cinta yaitu kasih yang Tuhan taruh di dalam diri setiap manusia. Itulah sebabnya setiap orang selalu mau dicintai dan mencintai. Pada dasarnya setiap orang yang normal fisik dan jiwanya selalu ingin dikasihi dan mengasihi. Jadi setiap orang sesungguhnya selalu ada naluri atau keinginan untuk mencintai dan dicintai atau dikasihi dan mengasihi. Maka sesungguhnya tidak ada alasan bagi seseorang untuk tidak bisa menghargai, mengasihi, atau mencintai orang lain karena kasih itu sudah ada dalam diri setiap orang yang lahir ke dunia. Oleh karena itu, mari makin menghargai/mengasihi orang lain apa adanya sehingga makin memanusiakan manusia.

Setiap orang yang beragama pasti mengakui bahwa ada perintah dalam agama masing-masing untuk menghargai/mengasihi orang lain. Sesungguhnya menghargai orang lain itu adalah hukumnya wajib, sehingga setiap orang yang tidak dapat menghargai orang lain harus ditegur atau dihukum. Rupanya kesadaran ini belum disadari, sehingga penghargaan terhadap sesama di sana-sini masih kurang dan bahkan cenderung melukai perasaan orang lain. Sesungguhnya manusia yang beragama adalah manusia yang mampu bukan hanya menghormati Tuhan melainkan juga menghargai/mengasihi orang lain. Jika tidak, sesungguhnya manusia tersebut adalah orang-orang yang munafik, seperti serigala berbulu domba. Padahal hati manusia itu adalah serigala yang berbalutkan agama.

Hal yang mendasari/melandasi seorang harus menghargai orang lain adalah kesadaran sosial. Kesadaran sosial artinya bahwa setiap manusia harus benar-benar mengerti dan sadar bahwa setiap orang pasti saling membutuhkan dan saling melengkapi. Hendaknya setiap orang benar-benar menyadari hal ini. Setiap orang tidak mungkin bisa hidup sendiri. Dari mulai lahir ke dunia ini, dari sejak itu juga seseorang membutuhkan orang lain yaitu orangtua dan lainnya. Oleh sebab itu, manusia sungguh saling membutuhkan untuk kebahagiaan dan kesempurnaan. Kebahagiaan dan kesempurnaan tidak akan lengkap tanpa kehadiran orang lain dalan kehidupan. Ruman dkk (2013:11) mengatakan: "Manusia bukan hanya individu, melainkan pada saat yang sama manusia juga adalah sosial. Bahkan sosialitas manusia menjadi juga hakekat dasar manusia. Manusia tidak dapat hidup tanpa orang lain.” Karl Max (Purdue, 1986:312) mengemukakan: "Sociability merupakan salah satu hakikat dasar dari manusia. Sosiabilitas manusia tidak hanya dikaitkan dalam konteks kerja sama untuk memenuhi kebutuhan manusia. Namun lebih dari sekedar kerja sama, manusia hanya dapat berkembang sebagai pribadi dalam kebersamaan dengan orang lain.” Laki-laki membutuhkan perempuan, demikian juga sebaliknya. Anak-anak membutuhkan orang tua demikian juga sebaliknya. Ketika seorang sudah menjadi tua, sekuat dan sehebat apapun dia ketika masih muda tetap pada masa tuanya membutuhkan 
anak dan orang lain. Ketika seorang sakit juga membutuhkan dokter. Bahkan seorang presiden sekalipun membutuhkan tukang cukur dan tukang urut. Itulah roda kehidupan, yang saling memberi dan menerima. Ada kalanya seorang memberi pertolongan dan ada kalanya seorang menerima pertolongan. Karena itu mari sungguh-sungguh menyadari hal ini, bahwa manusia saling membutuhkan.

Setiap orang harus sadar bawa dirinya adalah makhluk sosial yang punya tanggung jawab sosial, baik terhadap lingkungan maupun terhadap sesama. Tanggung jawab sosial terhadap sesama antara lain yaitu melindungi, menghargai, memajukan, dan lain lain. Oleh karena itu jika dilihat dari segi tanggung jawab sosial, sudah seharusnya setiap orang menghargai orang lain dan memperlakukannya dengan baik.

Hak Asasi Manusia (HAM) juga menjadi dasar seseorang menghargai orang lain, mengingat hak asasi manusia adalah piagam PBB (Perserikatan Bangsa-Bangsa) yang harus ditaati dan dilaksanakan oleh seluruh anggota PBB. Oleh karena itu, setiap orang harus menyadari hal ini dengan tulus dan penuh tanggung jawab, bahwa setiap orang berhak untuk mencintai dan dicintai. Hendaknya setiap orang menjunjung tinggi HAM dalam kehidupan sehari-hari. Penegakan HAM adalah kebutuhan dasar manusia di mana pun dia berada. HAM harus menjadi dasar hubungan dengan orang lain.

Hal lain yang mendasari seorang harus menghargai orang lain adalah penerimaan dan penghargaan terhadap orang lain. Seseorang akan mengalami kesulitan bahkan tidak mempu menghargai orang lain (merusak orang lain) jika dirinya belum mampu menerima dan menghargai orang lain. Sebagai contoh, orang yang menganggap dirinya tidak berharga, kotor, dan najis maka orang dalam kondisi seperti itu akan sulit untuk menghargai orang lain karena dia tidak menghargai dirinya sendiri. Jika seseorang mampu mengasihi dirinya, sesungguhnya orang seperti ini akan mampu memancarkan kasih dengan mengasihi/menghargai orang lain karena dia sendiri telah mengalami betapa indahnya kasih itu. Karena itu mari mulai penghargaan dan kasih itu dalam diri masing-masing, sehingga hal tersebut menjadi gaya hidup (habit) di dalam mengasihi/menghargai diri sendiri dan orang lain. Siapa pun yang tidak dapat menghargai orang lain sesungguhnya dia belum mampu menghargai dirinya sendiri.

\section{Orang yang Patut Dihargai}

Menghargai orang lain tidak boleh diskriminatif. Menurut Boediono (n.d.), kata diskriminatif berasal dari kata diskriminasi yang artinya adalah perbedaan perlakuan terhadap sesama warga negara, perbedaan warna kulit. Sedangkan Yosafat (2010) mengatakan bahwa diskriminasi biasanya mengacu pada tindakan membedakan seseorang dari yang lain bukan berdasarkan keunggulan yang dimiliki namun berdasarkan prasangka atau berdasarkan sikap-sikap yang secara moral tercela. Jadi menghargai orang lain harus tulus, jujur, dan sungguh-sungguh tanpa bersikap dikriminasi. Seseorang harus menghargai orang lain bukan hanya orang yang seagama, melainkan juga kepada semua orang baik yang seagama maupun yang tidak seagama.

Hal ini perlu ditekankan agar penghargaan tidak bersifat sektarian; bukan hanya orang yang baik melainkan juga orang yang jahat, sekalipun dia jahat kepada kita; bukan hanya orang yang tampan dan cantik melainkan juga orang yang jelek atau cacat sekalipun; bukan hanya orang kaya dan pejabat namun juga orang miskin, orang sederhana, orang biasa, orang tidak berpangkat atau tidak bertitel; bukan hanya bangsa, suku tertentu atau etnis tertentu melainkan juga semua bangsa, suku, dan etnis. Kasih Tuhan diberikan kepada setiap orang tanpa membeda-bedakan. Jika Tuhan begitu menyayangi (menghargai) manusia, di mana pun juga sudah seharusnya manusia berlaku demikian. 


\section{Penyebab Orang Tidak atau Kurang Menghargai Orang Lain}

Berikut ini adalah hal-hal yang menyebabkan manusia tidak dapat atau kurang mampu menghargai orang lain.

Manusia yang berdosa apalagi yang bergelimang dosa (dikuasai dosa) akan sulit menghargai orang lain. Jangankan menghargai orang lain, menghargai dirinya sendiri pun sulit. Karena orang berdosa cenderung menganggap dirinya najis, kotor, dan tidak berharga, perlakuan terhadap orang lain cenderung seperti itu juga. Pertobatan diperlukan agar seseorang dapat menghargai orang lain. Setiap orang harus berani mengambil sikap yang tegas untuk bertobat dari perbuatan-perbuatan dosanya (termasuk tidak menghargai orang lain) sesuai agama masing-masing. Orang yang bertobat akan lebih mudah menghargai orang lain karena dia akan ditolong oleh Tuhan untuk mampu melakukannya. Menyadari bahwa jauh lebih mudah jika kita melakukan dengan melibatkan Tuhan.

Pepatah berkata bahwa orang bisa karena biasa (habit). Jika seorang biasa berbuat baik, tentulah dia akan mudah untuk menghargai orang lain. Kebiasaan buruk atau pengalaman buruk yang selalu tersimpan di hati atau pikiran seperti: trauma, dendam, tidak mau mengampuni, malas, acuh tak acuh, dan lain-lain akan sulit menghargai orang lain. Jadi seorang harus membiasakan diri menghargai orang lain dimulai dari diri sendiri dan keluarga. Manusia harus membuang segala kebiasaan atau karakter yang tidak baik terutama dendam dari hidup, agar manusia merdeka dan menjadi manusia yang baik dan mulia.

Hal berikut yang menyebabkan seorang tidak dapat atau kurang mampu menghargai orang lain adalah egoism, yaitu sikap mementingkan diri sendiri dan mengabaikan kepentingan orang lain. Selama seseorang masih tetap bersikap egois, maka dia akan sulit untuk menghargai orang lain bahkan kemungkinan bisa terjadi menghancurkan orang lain. Sikap egoisme harus dibuang jauh-jauh dari kehidupan agar menjadi berkat bagi orang lain. Gea dkk (2004:250) mengatakan: "Bagi orang yang masih terbelenggu oleh kekangan egoismenya akan sulit untuk mengalihkan perhatiannya kepada orang lain. Dia hanya terpusat pada dirinya sendiri, memikirkan dirinya dan pemenuhan keinginannya secara tak terkendali. Hanya orang yang mampu melawan egoismenya mampu keluar dari dirinya, untuk mengarahkan perhatian dan memberikan cinta yang tulus kepada sesame." Karena itu mari membuang sifat egoistis, sehingga hubungan di antara manusia makin akrab dan makin saling menghargai serta menghormati.

Penyebab lain yang mengakibatkan seorang tidak dapat atau tidak mampu menghargai orang lain adalah ketidakmampuan menolak segala pengaruh yang negatif. Ketidakmampuan tersebut disebut juga keinginan rendah dalam diri, antara lain iri hati, dengki, gengsi, jaga image, malas memberi pujian. Selain itu, orang takut harga diri hilang jika memberi penghargaan terhadap orang lain dan tidak bisa menerima kelebihan orang lain.

Penyebab lain adanya sebagian orang yang selalu merasa dirinya di atas yang lain atau menganggap dirinya lebih tinggi/hebat dari orang lain. Ini mungkin dipengaruhi oleh adanya kelaskelas sosial pada zaman dahulu. Sikap stereotip adalah sikap yang cenderung menganggap dirinya lebih berharga dari yang lain yaitu sikap superior dari yang lain. Hal ini masih banyak dijumpai dalam praktik dan realitas hidup zaman sekarang. Oleh karena itu, sikap ini harus dibuang karena akan menghambat penghargaan terhadap orang lain secara adil.

Penyebab lain adalah makin banyak orang tidak memedulikan ajaran agama atau ajaran Tuhan Allah, etika, dan moral. Sekarang ini ada kecendrungan manusia menjadi individualis bukan sosialis, sehingga manusia cenderung menjadi hedonis yaitu mencari kenikmatan diri sendiri tidak mau pusing dengan orang lain atau tidak mau peduli kepada orang lain. Dalam hal ini seorang perlu disadarkan dan diingatkan lewat pengajaran yang sungguh-sungguh di dalam sekolah formal maupun nonformal 
agar penghargaan terhadap sesama tetap terpelihara dengan baik dan makin nyata, dan bukan sebaliknya semakin tergerus atau tererosi dengan sikap individulisme dengan segala turunannya.

Hal lain yang menyebabkan seseorang tidak dapat menghargai orang lain adalah prasangka dan diskriminasi. Prasangka adalah preseden (keputusan diambil atas dasar pengalaman masa lalu), pengambilan keputusan tanpa penelitian dan pertimbangan yang cermat, tergesa-gesa, atau tidak matang atau pelibatan unsur emosional (suka-tidak suka) dalam pengambilan keputusan. Prasangka tidak hanya terjadi pada orang yang sederhana tetapi juga orang yang pintar. Sedangkan diskriminasi dalam Boediono (n.d.) adalah perbedaan perlakuan terhadap sesama warga negara, perbedaan warna kulit. Mengenai prasangka dan diskriminasi, Soelaeman (2001:293) mengatakan: "Prasangka dan diskriminasi adalah dua hal yang ada relevansinya. Kedua tindakan tersebut dapat merugikan pertumbuhan, perkembangan dan bahkan integrasi masyarakat. Dari peristiwa kecil yang menyangkut dua orang meluas dan menjalar melibatkan sepuluh orang, golongan, atau wilayah, disertai tindakantindakan kekerasan dan destruktif yang merugikan.” Berdasarkan penjelasan, sebaiknya prasangka dan diskriminasi dibuang jauh jauh dari kehidupan, terutama prasangka buruk atau prasangka berlebihan demi makin terwujudnya saling menghargai secara tulus dan sungguh sungguh.

Beberapa hal yang dapat dilakukan agar seseorang dapat dan makin menghargai orang lain, yaitu: (1) menerima diri apa adannya dan bersyukur kepada Tuhan, Sang pemberi kehidupan; (2) membiasakan diri untuk selalu hidup baik di mana pun dan kapan pun; (3) hidup dalam kasih agar selalu menebarkan kasih dan penghargaan kepada sesame; (4) membuang sikap mementingkan diri sendiri; (5) mengingat selalu bahwa makhluk sosial (yang saling membutuhkan) dan punya tanggung jawab sosial untuk melindungi dan menghargai orang lain; (6) menjalankan agama dengan penuh ketaatan kepada Tuhan dan penghargaan kepada sesame; (7) membuang segala pikiran negatif (jahat) dan prasangka berlebihan (buruk) terhadap sesama; (8) tidak bersikap dan bertindak diskriminatif kepada siapa pun; (9) menjadi pelopor perdamaian dengan selalu menghargai orang lain di mana pun dan kapan pun; (10) menjadi penegak HAM di mana pun dan kapan pun.

\section{SIMPULAN}

Menghargai orang lain berarti memperlakukan orang lain secara baik dan benar, baik lewat perkataan maupun perbuatan. Matius 7 ayat 12 (LAI, 2009) mengatakan: "Segala sesuatu yang kamu kehendaki supaya orang perbuat kepadamu, perbuatlah demikian juga kepada mereka. Itulah isi seluruh hukum Taurat dan kitab para nabi.” Menghargai orang lain adalah wujud ketaatan kepada Tuhan. Jadi siapapun yang tidak mampu mengharagai orang lain, sesungguhnya dia adalah pendusta, munafik, dan tidak taat kepada Tuhan, Sang pencipta manusia. Sikap merendahkan, melecehkan, melakukan tindakan kekerasan apalagi pembunuhan sesungguhnya bertentangan dengan hukum, ajaran Tuhan, dan hukum kemanusian. Ketidakmampuan menghargai orang lain sesungguhnya adalah juga melanggar HAM yang melekat pada diri setiap orang yang lahir di bumi. Karena itu, manusia tidak boleh berpangku tangan atau berdiam diri tanpa berbuat apa-apa, manusia harus mulai dari diri sendiri; tidak boleh hanya manis di bibir namun pahit dalam perbuatan. Kata dan perbuatan harus sejalan, "jangan ada dusta di antara kita”, karena sesungguhnya manusia mampu untuk saling menghargai dan mengasihi. Menghargai orang lain bukan karena semata-mata ia baik namun karena ia manusia yang layak diharagai dan dihormati. 


\section{DAFTAR PUSTAKA}

Boediono. (n.d.) Kamus Lengkap Bahasa Indonesia. Jakarta: Bintang Indonesia.

Gea, A. A., Rahmat, N., Wulandari, A. P. Y. (2004). Relasi dengan Tuhan. Jakarta: Elex Media Komputindo.

LAI. (2009). Alkitab. Jakarta: Lembaga Alkitab Indonesia.

Ruman, Y. S., Gea, A. A., \& Irawan, I. (2013). Diktat Materi Mata Kuliah Interpersonal Development. Jakarta: Universitas Bina Nusantara.

Soelaeman, M. M. (2001). Ilmu Sosial Dasar. Bandung: Refika Aditama.

Stott, J. ( 1994). Isu-isu Global. Jakarta: Yayasan Komunikasi Bina Kasih/OMF.

Yosafat, B. (2010). Integritas Pemimpin Pastoral. Yogyakarta: ANDI 